\title{
Molecular Cloning of Ruminococcus albus Cellulase Gene
}

\author{
Shuji KaWaI, ${ }^{*}$ Hiroyuki Honda, Takaaki TanaSe, \\ Masahito Taya, Shinji IuJma \\ and Takeshi KOBAYASHI \\ Department of Chemical Engineering, Faculty of Engineering, \\ Nagoya University, Furo-cho, Chikusa-ku, Nagoya 464, Japan
}

Received June 2, 1986

\begin{abstract}
The gene directing the synthesis of the $\beta$-1,4-endoglucanase (1,4-D-glucan glucohydrase) (EC 3.2.1.4) of Ruminococcus albus F-40 was cloned in Escherichia coli C600. The recombinant plasmid pRA1 contained a 3.6 kilobase pair(kb)-Hind III fragment derived from $R$. albus. Forty-five percent of the cellulase activity encoded by pRA1 was detected in the periplasmic space and the remaining $55 \%$ was in the inner cellular fraction. The optimum $\mathrm{pH}$ and temperature of the cloned enzyme were pH 5.7 and $37^{\circ} \mathrm{C}$, respectively. The enzyme could digest carboxymethyl cellulose (CMC) and lichenan, but it was inactive for laminarin, xylan, and cellobiose.
\end{abstract}

The bioconversion of cellulosic material into useful products has become one of the important fields of biotechnology during past decade. For this, we have isolated several cellulolytic, anaerobic thermophiles from hot springs and compost samples and characterized their cellulolytic activity. ${ }^{1 \sim 3)}$ Recently, we had cloned several cellulase genes to increase the enzyme production and to understand the nature of the cellulase enzyme complex.

Rumen anaerobes act in cellulose digestion by ruminants for energy utilization. Among them, Ruminococcus albus, isolated from bovine rumen, had the strongest cellulase activity. ${ }^{4)}$ For the efficient production of the $R$. albus cellulase, the composition of a complete synthetic medium without rumen juice was established $^{5)}$ and mutants with higher cellulase activities were isolated. ${ }^{6}$ )

For the effective production and use of the $R$. albus cellulase, we have cloned an $\beta-1,4-$ endoglucanase gene of the bacterium in Escherichia coli. We have also studied the enzymatic properties of the cloned cellulase.

\section{MATERIALS AND METHODS}

Bacterial strains. R. albus F-40 was cultivated anaerobically at $37^{\circ} \mathrm{C}$ as described previously. ${ }^{5)}$ After the complete consumption of ball-milled cellulose suspended in the medium, the cells were harvested. E. coli C600 ( $h s d R$, $h s d M$, thil, leuB6) and the recombinants were cultivated in Luria-Bertani (L-broth) medium at $37^{\circ} \mathrm{C}$. When necessary, ampicillin $(50 \mu \mathrm{g} / \mathrm{ml})$ and tetracycline $(12 \mu \mathrm{g} / \mathrm{ml})$ were added to the medium.

Isolation of DNA. Chromosomal DNA was purified from $R$. albus cells by the method of Saito and Miura. ${ }^{7)}$ Plasmid DNAs were purified by cesium chloride-ethydium bromide gradient centrifugation. ${ }^{8)}$

Construction of recombinant plasmid. Chromosomal DNA isolated from $R$. albus F-40 was partially digested with HindIII and ligated to dephosphorylated-HindIIIcut pBR322 by T4 DNA ligase. E. coli C600 was transformed with the ligated DNA by the method of Norgard. ${ }^{9)}$ Restriction enzymes, E. coli alkaline phosphatase, and T4.DNA ligase were purchased from Takara Shuzo Co. and used as recommended by the supplier.

Selection of recombinants producing cellulase. Ampicillinresistant transformants were transferred by toothpicks to L-broth agar containing $50 \mu \mathrm{g} / \mathrm{ml}$ of ampicillin. After overnight incubation of the plates at $37^{\circ} \mathrm{C}, 5 \mathrm{ml}$ of $0.5 \%$ agar solution containing $0.5 \% \mathrm{CMC}, 0.1 \mathrm{mg} / \mathrm{ml}$ of egg white lysozyme (Seikagaku Kogyo), and $50 \mathrm{~mm}$ potassium 
phosphate buffer, $\mathrm{pH} 7.0$, was overlayed. The plates were incubated at $37^{\circ} \mathrm{C}$ for $4 \mathrm{hr}$ for the enzyme reaction and then $1 \mathrm{mg} / \mathrm{ml}$ of Congo red (Wako Pure Chemicals) solution was added. After $1 \mathrm{hr}$, the dye was discarded and the plates were washed with $1 \mathrm{M} \mathrm{NaCl}$ for $1 \mathrm{hr}$. Cellulase activity was detected as clear zones around colonies.

Assay of cellulase activity. One milliliter of the enzyme solution was mixed with $2 \mathrm{ml}$ each of $1 \% \mathrm{CMC}$ solution and $0.1 \mathrm{M}$ phosphate buffer, $\mathrm{pH} 6.0$. The reaction mixture was incubated for $45 \mathrm{~min}$ at $37^{\circ} \mathrm{C}$, then the reaction was stopped by boiling for $15 \mathrm{~min}$. Reducing sugar produced was measured by the Somogyi-Nelson method. ${ }^{10)}$ Liquefying activity was measured by the viscosity of the reaction mixture at suitable intervals with an Ostwald viscometer at $37^{\circ} \mathrm{C}$. One unit of enzyme activity was defined as that forming $1 \mu \mathrm{mol}$ of glucose equivalent of reducing sugar per minute.

To find the substrate specificity, the following concentrations of substrates were incubated with enough of the enzyme solution in $50 \mathrm{~mm}$ potassium phosphate buffer, $\mathrm{pH}$ 6.0 , at $37^{\circ} \mathrm{C}$ for $2 \mathrm{hr}$ : $p$-nitrophenyl- $\beta$-D-glucoside (PNPG), $10 \mathrm{~mm} ; \quad p$-nitrophenyl- $\beta$-D-cellobioside (PNPC), $10 \mathrm{~mm}$; cellobiose, $1 \%$; xylan, $1 \%$; laminarin, $1 \%$; and lichenan, $1 \%$. The xylose and glucose produced were measured by the Somogyi-Nelson method and by Glucostat reagent kits (Worthington Biochemical Corp.), respectively. Hydrolysis of PNPG and PNPC was monitored spectrophotometrically at $405 \mathrm{~nm}$.

Analysis of cellular distribution of the enzyme. E. coli C600 harboring a recombinant plasmid, pRA1, was cultured in L-broth at $37^{\circ} \mathrm{C}$. Cells were harvested at the late logarithmic growth phase. After removal of the medium, cells were fractionated by the method of Kato et al. ${ }^{11)}$ In addition to cellulase activity, $\beta$-lactamase ${ }^{12)}$ and $\beta$-galactosidase $^{131}$ activities were measured as controls.

\section{RESULTS}

\section{Cloning of $R$. albus cellulase gene}

Among $10^{4}$ ampicillin resistant colonies checked, 3 colonies had distinct cellulase activity on the CMC-Congo red plate. Recombinant plasmids of these transformants were designated pRA1, pRA2, and pRA3. pRA1 contained a single $3.6 \mathrm{~kb}$ Hind III fragment, while pRA2 contained 1.1, 2.1, and $3.6 \mathrm{~kb}$ HindIII DNA fragments and pRA3 contained $0.6,3.6$, and $3.9 \mathrm{~kb}$ fragments. Restriction enzyme analyses indicated that these 3 plasmids contained a common $3.6 \mathrm{~kb}$ DNA fragment (data not shown). Thus, pRA1 which had only this fragment was used for

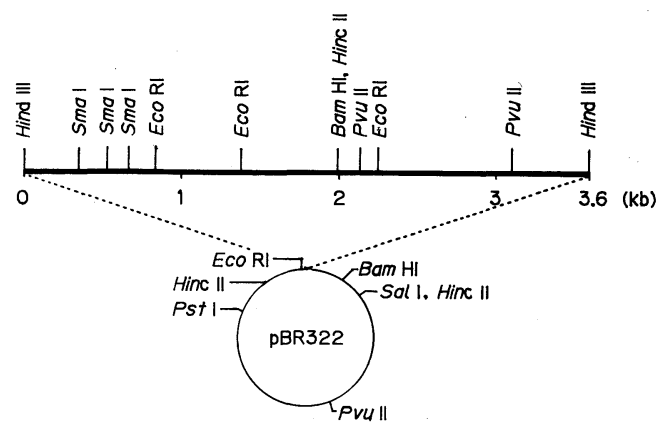

FIG. 1. Physical Map of pRA1 Constructed with pBR322 and the HindIII Fragment Containing the $R$. albus Cellulase Gene.

further study. The direction of the insert in pRA2 was opposite to that of pRA1, judging by the restriction enzyme analysis.

pRA1 was digested with several restriction enzymes and analyzed by agarose gel electrophoresis. Figure 1 shows the restriction map of the plasmid. The DNA fragment contained neither Sal I, PstI, BglII, HpaI, PvuI, $X b a \mathrm{I}$, nor $X h o \mathrm{I}$ sites. No cellulase activity was detected when the $1.6 \mathrm{~kb}$ Bam HI-HindIII fragment was removed.

To confirm that the cloned DNA fragment was derived from $R$. albus chromosomal DNA, the HindIII fragment of pRA1 was isolated, ${ }^{32} \mathrm{P}$-labeled by nick translation, and hybridized with HindIII digested $R$. albus, Thermoanaerobacter cellulolyticus, Clostoridium thermocellum, and E. coli chromosomal DNAs by the method of Southern. ${ }^{14)}$ As shown in Fig. 2, the probe could hybridize only to the $3.6 \mathrm{~kb}$ HindIII fragment from $R$. albus. This clearly indicates that the isolated DNA fragment is derived from $R$. albus.

To study whether the cellulase gene on the plasmid was transcribed from its own promoter or not, the recombinant plasmid pRA11 which contained the gene in the opposite direction was constructed from pRA1 by HindIII cleavage and religation. We isolated 3 independent clones which had pRA11. The direction of the gene was found from the pattern of EcoRI cleavage. Because no cellulase activity was observed in these clones, the 


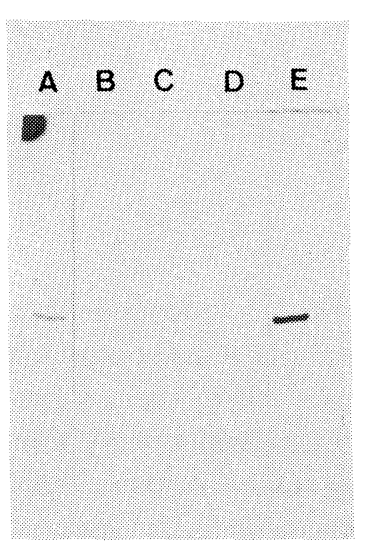

FIG. 2. Southern Blot Hybridization of a ${ }^{32} \mathrm{P}$-Labeled HindIII Fragment Encoding the Cellulase Gene of $R$. albus to HindIII Digested Chromosomal DNAs from Various Bacteria.

Five microgram of chromosomal DNAs and $0.1 \mu \mathrm{g}$ of pRA1 DNA were cut with HindIII, fractionated on a $0.8 \%$ agarose gel, transferred to a nitrocellulose filter, and hybridized with the ${ }^{32} \mathrm{P}$-labeled $3.6 \mathrm{~kb}$ HindIII fragment of pRA1. The period of exposure was one day. A, R. albusHindIII: B, T. cellulolyticus-HindIII; C, C. thermocellumHindIII; D, E. coli-HindIII; E, pRA1-HindIII.

$3.6 \mathrm{~kb}$ Hind III fragment does not contain a promoter acting in E. coli. The gene may be expressed by a promoter on the vector plasmid.

\section{Enzymatic properties of cloned cellulase}

Cellulolytic bacteria usually contain multiple cellulases. Therefore, characterization of their properties has been impossible without separating them from each other. In the recombinant clone carrying pRA1, only a single cellulase species was assumed to be expressed. Thus, we characterized the enzyme encoded by pRA1 and pRA2.

The cellulase encoded by pRA1 could hydrolyze CMC which contained $\beta-1,4$ linkages but it could not hydrolyze the $\beta-1,3$ linkages of laminarin. No detectable enzyme activity was observed with xylan, cellobiose, PNPC, or PNPG. Table I summarizes the substrates specificity of the enzyme.

Viscosity changes of the CMC solution caused by the enzyme encoded by pRA1 were monitored and plotted against the amount of
Table I. Substrate Specificity of the Cellulase ENCODED BY pRA1

\begin{tabular}{|c|c|c|}
\hline \multirow{2}{*}{ Substrate } & \multicolumn{2}{|c|}{$\begin{array}{l}\text { Enzyme specific activity } \\
\text { (U/mg-protein) }\end{array}$} \\
\hline & pRA1 & $\mathrm{pBR} 322^{a}$ \\
\hline $\operatorname{CMC}(\beta-1,4)$ & $2.8 \times 10^{-3}$ & $1.3 \times 10^{-5}$ \\
\hline $\begin{array}{l}\text { Lichenan } \\
\qquad(\beta-1,3 \text { and } \beta-1,4)\end{array}$ & $1.2 \times 10^{-3}$ & $4.0 \times 10^{-5}$ \\
\hline Laminarin $(\beta-1,3)$ & $3.7 \times 10^{-5}$ & $4.0 \times 10^{-5}$ \\
\hline Xylan & not detectable & - \\
\hline Cellobiose & not detectable & - \\
\hline PNPC & $3.6 \times 10^{-7}$ & - \\
\hline PNPG & $2.9 \times 10^{-7}$ & - \\
\hline
\end{tabular}

a As a control, crude enzyme extract was prepared from the cells containing pBR322 and measured the enzyme activities. PNPG, $p$-nitrophenyl- $\beta$-Dglucoside, PNPC, $p$-nitrophenyl- $\beta$-D-cellobioside.

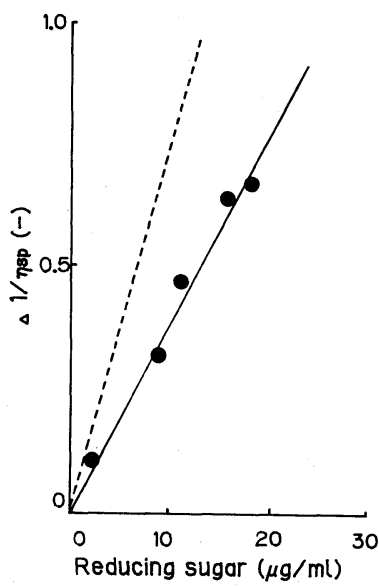

FIG. 3. Fluidity Changes of CMC versus the Amount of Reducing Sugar Released by the Action of the Cloned Enzyme at $\mathrm{pH} 7.0$ and $37^{\circ} \mathrm{C}$.

Broken line shows the typical result with C600/pCT104. The recombinant plasmid pCT104 contained the cloned $C$. thermocellum $\beta$-1,4-endoglucanase gene.

reducing sugar formed that were measured using the same samples (Fig. 3). Fluidity $\left(1 / \eta_{\mathrm{sp}}\right)$ of the CMC solution after the enzyme reaction increased with the amount of reducing sugar released. For comparison, a similar experiment was done with the crude enzyme extract of $E$. coli $\mathrm{C} 600 / \mathrm{pCT} 104$, which carried the $C$. thermocellum $\beta$-1,4-endoglucanase gene. ${ }^{15)}$

The optimum $\mathrm{pH}$ of the cloned cellulases encoded by pRA1 and pRA2 was 5.7 for both 


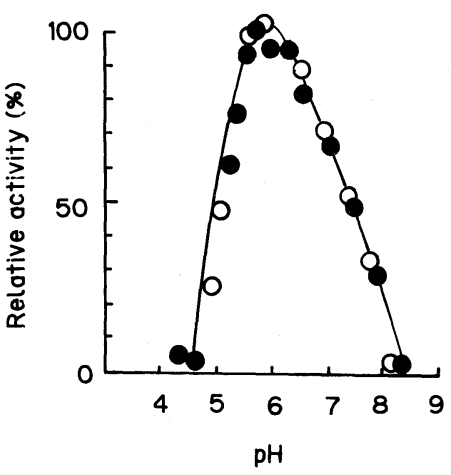

FIG. 4. Optimum $\mathrm{pH}$ for the Plasmid Encoded $\beta$-1,4Endoglucanase Activity at $37^{\circ} \mathrm{C}$.

The enzymes encoded by pRA1 (O) and pRA2 (O).

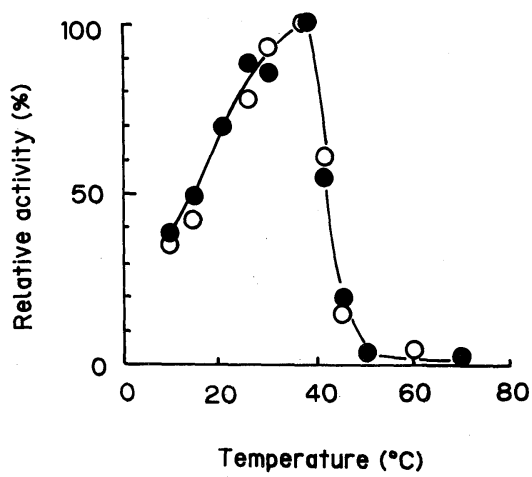

Fig. 5. Optimum Temperature for the Plasmid Encoded $\beta$-1,4-Endoglucanase Activity at $\mathrm{pH} 7.0$.

The enzymes encoded by pRA1 (O) and pRA2 (○).

enzymes as shown in Fig. 4. The optimum temperature was $37^{\circ} \mathrm{C}$ at $\mathrm{pH} 7.0$ and profiles of the temperature dependency of the enzyme reaction were indistinguishable between enzymes encoded by pRA1 and pRA2 (Fig. 5). These results indicated that the catalytic properties of cellulases encoded by pRA1 and pRA2 were the same as far as we have studied.

\section{Location of cellulase activity in the E. coli transformant}

The cellular location of the cellulase activity produced by the recombinant carrying pRA1 was found. Forty-five percent of the activity was detected in the periplasmic space and the remaining activity was in the inner cellular fraction. The findings that no $\beta$-galactosidase activity was detected in the medium and that about $90 \%$ of $\beta$-lactamase activity was located in periplasmic fraction indicate that the cells did not lyse.

\section{DISCUSSION}

We obtained 3 independent transformants which carried plasmids containing the $R$. albus cellulase gene. All of them shared a common $3.6 \mathrm{~kb}$ fragment which may contain the cellulase gene. One of these plasmid, pRA2, contained the gene in the opposite direction to the other two. We also constructed pRA11 from $\mathrm{pRA} 1$ in which the direction of the gene was the same as pRA2. Although the clone carrying pRA2 expressed considerable amounts of cellulase activity, the clone carrying pRA11 had none. The cellulase gene was flanked by additional DNA fragments from the $R$. albus chromosome in pRA2. Thus, one possible explanation of this discrepancy may be that the $3.6 \mathrm{~kb}$ DNA fragment did not contain a promotor acting in $E$. coli and the gene was expressed from the $\mathrm{P} 1$ promoter of $\mathrm{pBR} 322^{16)}$ in $\mathrm{pRA} 1$ and from a promoter of a flanking DNA sequence in pRA2. Although, cloned cellulase genes seem to be expressed by the different promoters, catalytic properties of the produced enzymes were indistinguishable, as far as we have studied. If cloned enzymes are fused to other proteins, these kinetic properties may be different from each other. Therefore, we assumed that these two enzymes encoded by the recombinant plasmids are identical to authentic enzyme produced by $R$. albus. To settle this point, further study including DNA sequencing may be needed. Recently, several cellulase genes were isolated from both aerobic and anaerobic bacteria, ${ }^{15.17 \sim 19)}$ and as far as we know, all of them were expressed in E. coli.

$R$. albus contained at least 3 different cellulases, endoglucanase, ${ }^{20)}$ cellobiosidase, ${ }^{21}$ ) and $\beta$-glucosidase. ${ }^{22)}$ Several lines of evidence suggest that the enzyme we had cloned is a $\beta$ 1,4-endoglucanase. First, the cloned enzyme could not hydrolyze PNPG, PNPC, or cel- 
lobiose. Second, the ratio of fluidity lowering to reducing sugar formed by the enzyme reaction was much higher than that obtained with purified cellobiosidase, ${ }^{21)}$ and the ratio was similar to that of $C$. thermocellum $\beta$-1,4endoglucanase cloned in E. coli (Fig. 3).

Recently, Maeda et al. purified a $\beta$-1,4endoglucanase from $R$. albus and reported that the optimum $\mathrm{pH}$ and optimum temperature for the enzyme reaction are 6.7 and $44^{\circ} \mathrm{C}$, respectively. ${ }^{20)}$ These values are slightly different from those obtained in this study with the enzyme encoded by pRA1 and pRA2. Thus, it is possible that the enzymes encoded by the recombinant plasmids are different from that purified by Maeda et al.

The $\beta$-1,4-endoglucanase of $R$. albus was reported to be secreted into the culture medium. $^{20)}$ In the recombinant $E$. coli carrying pRA $1,45 \%$ of the enzyme activity was found in the periplasmic space, while no enzyme activity was detected in the medium. This might be due to the diference of secretion machinery between $E$. coli and $R$. albus. Recently, we observed that about $60 \%$ of cellulase activity was secreted into the medium in E. coli C600 strain 09098 transformed with pRA1 (Kawai et al., unpublished result). This strain is a leaky mutant isolated by Warren. ${ }^{23}$

For effective bioconversion of cellulosic materials, coreaction of $\beta$-glucosidase and other cellulolytic enzymes in addition to $\beta$-1,4endoglucanase is necessary. We are now trying to isolate these genes from the anaerobe.

Acknowledgment. This work was supported in part by the Biomass Conversion Project of the Ministry of Agriculture, Forestry and Fisheries (BCP86-V-1-12). S. $\mathrm{K}$. wishes to thank $\mathrm{Kao} \mathrm{Co}$, for providing a chance for this work.

\section{REFERENCES}

1) M. Taya, Y. Suzuki and T. Kobayashi, J. Ferment. Technol., 62, 229 (1984).

2) M. Taya, H. Hinoki and T. Kobayashi, Agric. Biol. Chem., 49, 2513 (1985).

3) M. Taya, H. Hinoki, Y. Suzuki, T. Yagi and T. Kobayashi, J. Ferment. Technol., 63, 383 (1985).

4) M. Taya, Y. Ito, K. Ohmiya, T. Kobayashi and S. Shimizu, Nippon Nôgeikagaku Kaishi, 52, 567 (1978).

5) M. Taya, T. Kobayashi and S. Shimizu, Agric. Biol. Chem., 44, 2225 (1980).

6) M. Taya, K. Ohmiya, T. Kobayashi and S. Shimizu, J. Fermet. Technol., 61, 197 (1983).

7) H. Saito and K. Miura, Biochim. Biophys. Acta, 72 619 (1963).

8) T. Maniatis, E. F. Frisch and J. Sambrook, "Molecular Cloning," Cold Spring Harbor Laboratory, New York, 1982.

9) M. V. Norgard, K. Keem and J. J. Monohan, Gene, 3, 279 (1978).

10) N. Nelson, J. Biol. Chem., 153, 375 (1944).

11) C. Kato, T. Kudo, K. Watanabe and K. Horikoshi, Eur. J. Appl. Microbiol. Biotechnol., 18, 339 (1983).

12) T. Sawai and I. Takahashi, Protein, Nucleic Acid and Enzyme, 23, 391 (1978).

13) M. Bittner and D. Vapnek, Gene, 15, 319 (1981).

14) E. M. Southern, J. Mol. Biol., 98, 503 (1975).

15) P. Cornet, D. Toronik, J. Millet and J. P. Aubert, FEMS Microbiol. Lett., 16, 137 (1983).

16) S. Stuber and H. Bujard, Proc. Natl. Acad. Sci. U.S.A., 78, 167 (1981).

17) D. J. Whittle, D. G. Kilburn, R. A. J. Warren and R. C. Miller, Jr., Gene, 17, 139 (1982).

18) N. Sashihara, T. Kudo and K. Horikoshi, $J$. Bacteriol., 158, 503 (1984).

19) K. Koide, A. Nakamura, T. Uozumi and T. Beppu, Agric. Biol. Chem., 50, 233 (1986).

20) K. Maeda, K. Nagashima, K. Ohmiya and S. Shimizu, Abstracts of Papers, The Annual Meeting of Agricultural Society of Japan, Sapporo, July, 1985, p. 710.

21) K. Ohmiya, M. Shimizu, M. Taya and S. Shimizu, J. Bacteriol., 150, 407 (1982).

22) K. Ohmiya, M. Shirai, Y. Kurachi and S. Shimizu, $J$. Bacteriol., 161, 432 (1985).

23) N. R. Gilkes, D. G. Kilburm, R. C. Miller, Jr. and R. A. Warren, BIO/TECHNOL., 2, 259 (1984). 